\title{
The "Sea Diamond" shipwreck: environmental impact assessment in the water column and sediments of the wreck area
}

\author{
E. Dimitrakakis $\cdot$ J. Hahladakis $\cdot$ E. Gidarakos
}

Received: 27 November 2012/Revised: 22 January 2013/Accepted: 6 May 2013/Published online: 5 June 2013

(C) Islamic Azad University (IAU) 2013

\begin{abstract}
In the "Sea Diamond" shipwreck, it is estimated that almost 1.7 tons of batteries/accumulators and approximately 150 cathode ray tube technology televisions have gone to the bottom of the sea. Under these circumstances, all the aforementioned materials will eventually undergo severe accelerated corrosion. Consequently, a variety of heavy metals will either be released in seawater or precipitate in the form of salts resulting in contamination of the sea sediments. According to the ship data, and the aforementioned quantities of batteries and televisions, it is estimated that approximately $75-80 \mathrm{~g}$ of mercury, $630-1,050 \mathrm{~g}$ of cadmium and 1.14-1.26 tons of lead exist in the wreck only due to the electrical and electronic equipment present in the ship, not to mention the significant amount of heavy metals such as copper, nickel, ferrous and chromium that exist in the hulk. Four series of seawater sampling $(n=85)$ were conducted in different stations surrounding the wreck area in order to assess the overall impact from the release of heavy metals in the surrounding aquatic environment. The analysis indicated that there were stations where lead, zinc and cadmium were present in concentrations higher than the permissible limits set by the Unites States Environmental Protection Agency for seawater. Furthermore, the analysis of three series of sediment sampling $(n=31)$ from the wreck area showed elevated but expected concentration values for ferrous and
\end{abstract}

Electronic supplementary material The online version of this article (doi:10.1007/s13762-013-0331-z) contains supplementary material, which is available to authorized users.

E. Dimitrakakis · J. Hahladakis · E. Gidarakos $(\bowtie)$

Department of Environmental Engineering, Technical University

of Crete, Politechnioupolis, 73100 Chania, Greece

e-mail: gidarako@mred.tuc.gr manganese, considering the geological background of the area and contamination with lead, copper and cadmium.

Keywords Heavy metals - Seawater contamination · Sediment contamination $\cdot$ Shipwreck

\section{Introduction}

For as long as ships have been traveling upon the water of the earth, they have been sinking. There are many reasons for the demise of a vessel such as wild weather conditions, armed conflicts and navigational or other human errors (Rogowska and Namieśnik 2009). Although many studies have been carried out on the environmental effects following a sinking, especially of oil, fuels and cargo released in the sea, few of them have concentrated in the chemical pollution caused in seawater and surface sediments by the release of heavy metals (Jones 2007).

Heavy metals exist naturally in the sea column as well as in sea sediments in low concentrations (Ansari et al. 2004). Due to their low rate of biodegradation, they are considered to be persistent pollutants (Clark 2002). In a passenger ship, heavy metals are present almost everywhere (in the antifouling paints, in the electric and electronic equipment (EEE), in its hull and in the sacrificed anodes). The corrosion of all the aforementioned parts of a ship and consequently metals under seawater is a multifactorial process, influenced by both physicochemical and biological parameters. The most important of them are $\mathrm{pH}$, salinity, temperature, depth, electrical conductivity, velocity of sea currents and microorganisms. Each one of these parameters has an equally significant impact both individually and in combination with others (Phull 2010). Table 1a presents the most significant heavy metal 
Table 1 (a) Safety limits (criteria) set by the US EPA for concentrations of heavy metals in seawater and (b) ERL/ERM and TEL/PEL limit values for heavy metals in sediments

\begin{tabular}{|c|c|c|c|c|}
\hline Element & \multicolumn{2}{|c|}{ Criterion of maximum concentration $(\mathrm{CMC}, \mu \mathrm{g} / \mathrm{L})$} & \multicolumn{2}{|c|}{ Criterion of constant concentration $(\mathrm{CCC}, \mu \mathrm{g} / \mathrm{L})$} \\
\hline \multicolumn{5}{|l|}{ (a) } \\
\hline Cadmium (Cd) & 40.0 & & 8.8 & \\
\hline Copper $(\mathrm{Cu})$ & 4.8 & & 3.1 & \\
\hline Lead $(\mathrm{Pb})$ & 210.0 & & 8.1 & \\
\hline Nickel (Ni) & 74.0 & & 8.2 & \\
\hline Chromium (Cr (VI)) & $1,100.0$ & & 50.0 & \\
\hline Zinc $(\mathrm{Zn})$ & 90.0 & & 81.0 & \\
\hline Mercury (Hg) & 1.8 & & 0.94 & \\
\hline Arsenic (As) & 69 & & 36 & \\
\hline Element & $\mathrm{ERL}(\mathrm{mg} / \mathrm{kg} \mathrm{dw})$ & $\mathrm{ERM}(\mathrm{mg} / \mathrm{kg} \mathrm{dw})$ & TEL (mg/kg dw) & PEL $(\mathrm{mg} / \mathrm{kg} \mathrm{dw})$ \\
\hline \multicolumn{5}{|l|}{ (b) } \\
\hline $\mathrm{Pb}$ & 46.7 & 218 & 30.2 & 112 \\
\hline $\mathrm{Cd}$ & 1.2 & 9.6 & 0.68 & 4.21 \\
\hline $\mathrm{Cr}$ & 81 & 370 & 52.3 & 160 \\
\hline $\mathrm{Ni}$ & 20.9 & 51.6 & 15.9 & 42.8 \\
\hline $\mathrm{Hg}$ & 0.15 & 0.71 & 0.13 & 0.7 \\
\hline $\mathrm{Zn}$ & 150 & 410 & 124 & 271 \\
\hline $\mathrm{Cu}$ & 34 & 270 & 18.7 & 108 \\
\hline
\end{tabular}

concentration limits in seawater, set by the Unites States Environmental Protection Agency (US EPA 2009). Criterion maximum concentration $(\mathrm{CMC})$ is an estimate of the highest concentration of a material in surface water to which an aquatic community can be exposed briefly without resulting in an unacceptable effect, whereas criterion continuous concentration (CCC) stands for the highest concentration for indefinite exposure. Significant amount of heavy metals will also end up, in a short period of time, in sea sediments (Clark 2002). In fact, on the long run, sediments are the final recipient of heavy metals (Fytianos 1996). Table $1 \mathrm{~b}$ presents heavy metal concentration limits regarding two sets of guidelines (ERL/ERM and TEL/PEL) for assessing sediment contamination, which will be analyzed thoroughly in section "Application of SQGs for the contamination assessment of sediments from the surrounding wreck area" of the present work.

Many studies have attempted a thorough report concerning the consequences to the environment following a sinking. Prego and Cobelo-Garcia (2004) and SantosEcheandia et al. (2005) reported contamination from $\mathrm{Pb}$ to $\mathrm{Cu}$ in the Galician water column near the point of the "Prestige" shipwreck. Other scientists studied heavy metal contamination due to benzene or oil spills (Mirlean et al. 2001; Lin and $\mathrm{Hu}$ 2007; Bu-Olayan et al. 1998). Jones (2007) revealed contamination by $\mathrm{Cu}$ and $\mathrm{Zn}$ in sediments near the "Norwegian Crown" wreck, mainly attributed to the wearing of the antifouling (AF) paints.
Table 2 Estimated quantities of metals and heavy metals existing in "Sea Diamond" according to the Green Passport of the MS and the environmental study of TUC in the wreck area

\begin{tabular}{ll}
\hline Element & Estimated quantity $(\mathrm{kg})^{\mathrm{a}}$ \\
\hline Iron $(\mathrm{Fe})$ & $14,625^{\mathrm{a}}-14,629$ \\
Manganese (Mn) & $58,562-104,595$ \\
Copper $(\mathrm{Cu})$ & $7,652.5-11,657.3$ \\
Zinc $(\mathrm{Zn})$ & $1,169-6,751.7$ \\
Lead $(\mathrm{Pb})$ & $1,140-1,260$ \\
Chromium $(\mathrm{Cr})$ & $372.4-886$ \\
Cadmium $(\mathrm{Cd})$ & $0.63-1.05$ \\
Nickel $(\mathrm{Ni})$ & $38.43-1,497.4$ \\
Aluminum (Al) & $134-1,598.6$ \\
Vanadium (V) & 262 \\
Magnesium (Mg) & $47-81.2$ \\
Molybdenum (Mo) & $67-180$ \\
Mercury (Hg) & $0.075-0.080$ \\
\hline
\end{tabular}

${ }^{\text {a }}$ Quantities are in tons

In the present study, the authors focused on the evaluation of heavy metal contamination levels of the area surrounding the wreck of the MS "Sea Diamond" that took place on April 5, 2007, in the caldera of the island of Santorini, in Greece. Seawater samples $(n=85)$ were collected and analyzed in their metal concentrations. Moreover, sediment quality guidelines (SQGs) were applied in order to evaluate the total metal contents of 
Fig. 1 Sampling sites of the a first and $\mathbf{b}$ second series of seawater sampling
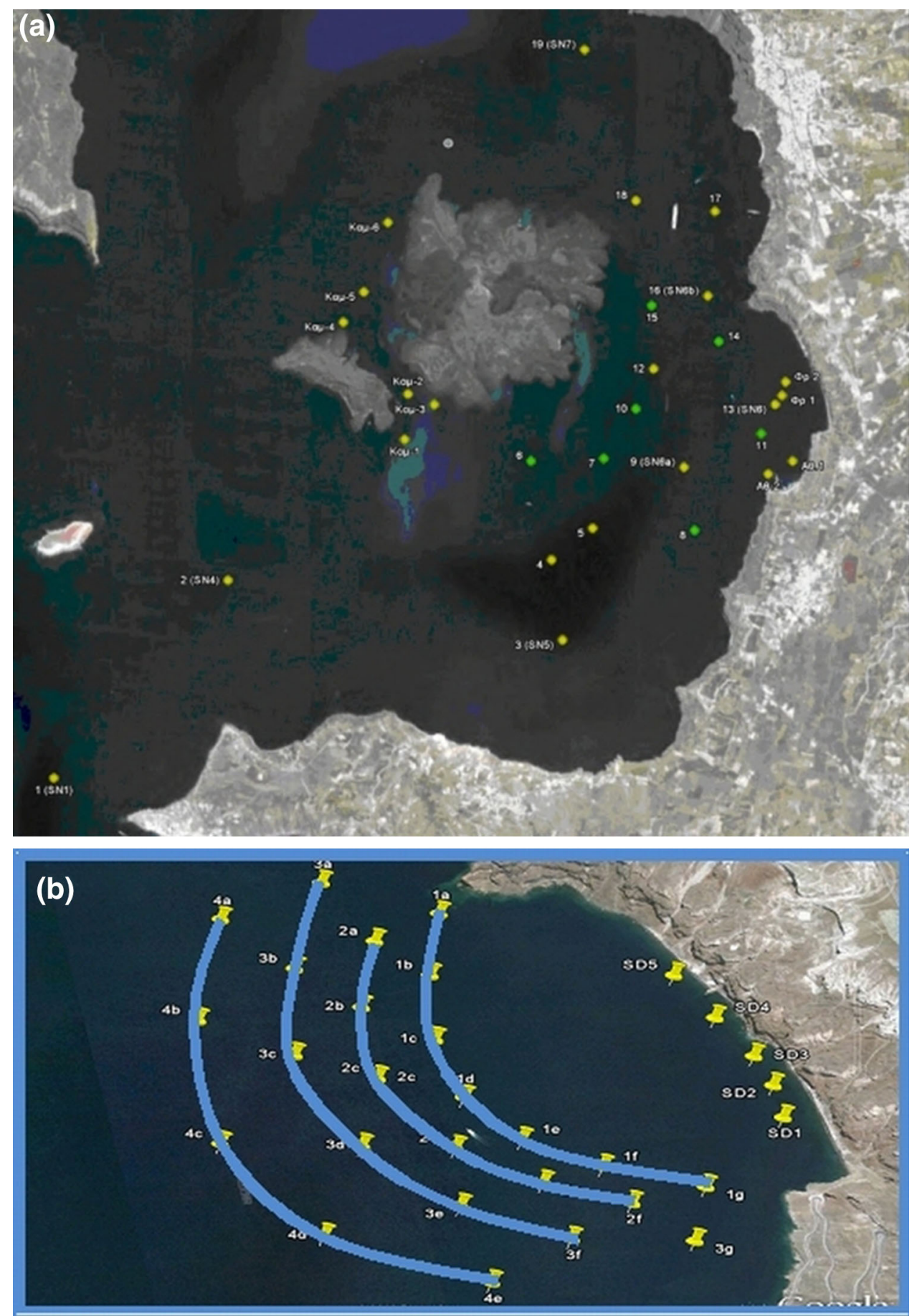

sediment samples $(n=31)$ collected from the area where the "Sea Diamond" shipwreck lies. Both seawater and sediment samples were collected during a sampling period of 6 months and, more specifically, between May and November 2010, approximately 3 years after the shipwreck took place in the Caldera of Santorini, Greece.
The shipwreck of the MS "Sea Diamond"

On April 5, 2007, at approximately 16:00 EEST, the MS "Sea Diamond" ran aground a reef, at the east side of Nea Kameni, an area within the caldera of the Greek island of Santorini, and began taking on water. After the collision, 
Fig. 2 Sampling sites of the $\mathbf{a}$ third and $\mathbf{b}$ fourth series of seawater sampling
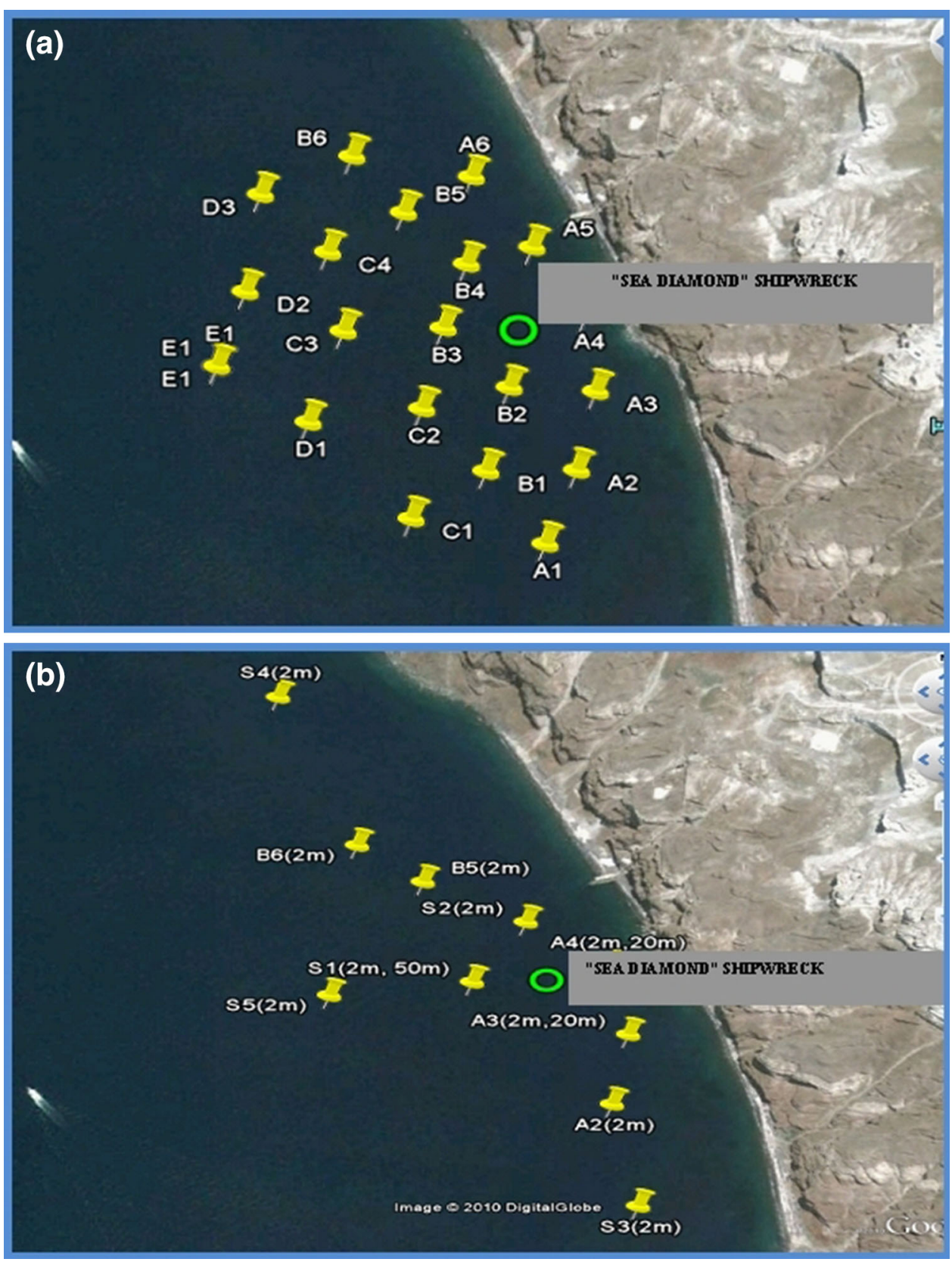

the ship was towed off the rocks, and her list was stabilized. The large amount of water taken on board led the ship to sink at about 7:00 EEST on April 6, 2007, just a few hundred meters from the shore. Video footage showed that, just before the stern was settled onto the bottom of the sea, the ship completely inverted. It was later reported that the tip of the bow was only $62 \mathrm{~m}$ below sea level, whereas the stern was in a depth of almost $180 \mathrm{~m}$, a fact that leads to an almost vertical sinking scenario. Keeping in mind the volcanic activity of the area, it is feared that the hull would either brake or slide deeper and sink into the submerged caldera of the island. It has been speculated that the deep, almost vertical shore of the bathtub-like caldera made it impossible to beach the ship and save it from becoming a total loss (http://en.wikipedia.org/wiki/MS_Sea_Diamond).

Quantity assessment of heavy metals existing in "Sea Diamond" shipwreck

A detailed study, concerning the current and long-term environmental impact of the wreck in the surrounding area, was assigned by the South Aegean Region to Technical University of Crete (TUC) and was conducted by a team of researchers from the Laboratory of Toxic and Hazardous Waste Management in TUC, under the supervision of Professor E. Gidarakos. The research team, which was 
Fig. 3 Sampling sites of all the three series of sediment sampling

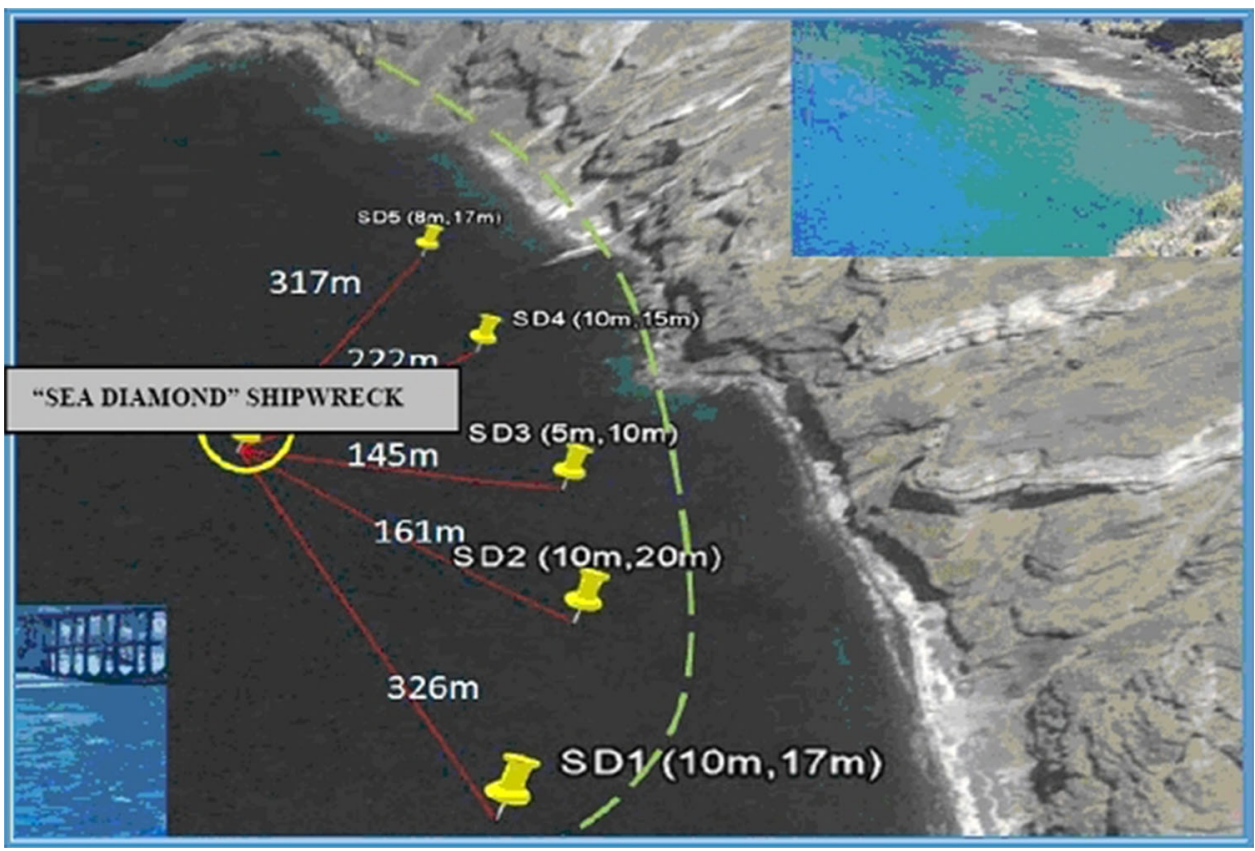

consisted of scientists from various scientific fields, after evaluating the results, suggested that such a wreck in such a closed sea like the Caldera of Santorini would make it a constant concern for the environment and that a salvage of the wreck should be mandatory (Gidarakos et al. 2011).

Table 2 presents an assessment of the total metal and heavy metal quantities existing in "Sea Diamond" shipwreck, according to the green passport of the ship and the Study of Environmental Impacts due to the shipwreck, conducted by the research team in the Laboratory of Toxic and Hazardous Waste Management of Technical University of Crete (Environmental Protection Engineering S.A. 2008; Gidarakos et al. 2011).

It is obvious that zinc, copper and manganese are the most abundant elements from a total content point of view. That, of course, is by no means a criterion for the environmental impact of these particular metals. Small quantities of certain elements (e.g., $\mathrm{Pb}, \mathrm{Cd}$ and $\mathrm{Hg}$ ) may have a far more disastrous effect on the aquatic environment (Schreiber and Burger 2002). Table 2 was built based on the initial data of the ship regarding its infrastructure, cargo and "Green Passport" along with the data resulted from the study conducted in TUC (Environmental Protection Engineering S.A. 2008; Gidarakos et al. 2011). However, one should keep in mind that there are sources of elements existing in various parts or materials of the ship that are impossible to be estimated. Such are fuels $(\mathrm{Cd}, \mathrm{Pb}$ and $\mathrm{Cu}$ ) (Prego and Cobelo-Garcia 2004), unknown Polyvinyl chloride (PVC) containing $\mathrm{Cd}$ as an element for its stabilizers, food metallic packages and many others. These quantities have not been included in our calculations.

\section{Materials and methods}

Sampling sites and sample collection

Four series of seawater sampling $(n=85)$ and three series of sediment sampling $(n=31)$ were carried out for the complete evaluation of the contamination of the wreck area. Figures 1 and 2 present the sampling sites of all the series regarding the water samples, and Fig. 3 shows the sampling sites of all the series of sediment samples. The coordinates of all the sampling sites are presented in Table 3.

All the water samples were collected from a depth of approximately $2 \mathrm{~m}$ by the use of a 10-L Niskin sampler. The samples were then placed in 250-mL HDPE (high density polyethylene) bottles which had been previously washed and stayed on nitric acid $10 \%$ over a week. The samples were acidified directly after sampling $\left(\mathrm{HNO}_{3}\right.$, Fluka, and nitric acid TraceSELECT Ultra for trace analysis), transported to the Laboratory of Toxic and Hazardous Waste Management in TUC within $24 \mathrm{~h}$ and filtered $(0.45 \mu \mathrm{m})$. The samples from all four series of seawater sampling were analyzed in the laboratories of TUC without undergoing any further dissolution. More specifically, samples were analyzed by the use of ICP-MS (Agilent 7500-CX) and according to standard EN ISO 11885 for all heavy metals, except mercury, which was measured according to EN 1483-E12-4.

The sediment samples were collected from the wreck area with the help of a diver, stored in HDPE bottles that were previously washed with $\mathrm{HNO}_{3} 10 \%$ and kept in $-4{ }^{\circ} \mathrm{C}$ until they were sent to the laboratories of TUC. The 
Table 3 Sampling sites and coordinates

\begin{tabular}{|c|c|c|c|}
\hline Sampling site & Coordinates & Sampling site & Coordinates \\
\hline \multicolumn{2}{|c|}{ First sampling series } & \multicolumn{2}{|c|}{ Second sampling series } \\
\hline \multirow[t]{2}{*}{$1(\mathrm{SN} 1)$} & $25^{\circ} 20^{\prime} 45.30^{\prime \prime}$ & 1a & $36^{\circ} 24^{\prime} 6.39^{\prime \prime}$ \\
\hline & $36^{\circ} 21^{\prime} 42.66^{\prime \prime}$ & & $25^{\circ} 25^{\prime} 29.29^{\prime \prime}$ \\
\hline \multirow[t]{2}{*}{2 (SN4) } & $25^{\circ} 21^{\prime} 58.80^{\prime \prime}$ & $1 b$ & $36^{\circ} 23^{\prime} 59.11^{\prime \prime}$ \\
\hline & $36^{\circ} 22^{\prime} 45.60^{\prime \prime}$ & & $25^{\circ} 25^{\prime} 26.25^{\prime \prime}$ \\
\hline \multirow[t]{2}{*}{3 (SN5) } & $25^{\circ} 24^{\prime} 14.28^{\prime \prime}$ & $1 \mathrm{c}$ & $36^{\circ} 23^{\prime} 51.23^{\prime \prime}$ \\
\hline & $36^{\circ} 22^{\prime} 22.62^{\prime \prime}$ & & $25^{\circ} 25^{\prime} 24.63^{\prime \prime}$ \\
\hline \multirow[t]{2}{*}{4} & $25^{\circ} 24^{\prime} 10.86^{\prime \prime}$ & $1 d$ & $36^{\circ} 23^{\prime} 37.43^{\prime \prime}$ \\
\hline & $36^{\circ} 22^{\prime} 48.96^{\prime \prime}$ & & $25^{\circ} 25^{\prime} 30.86^{\prime \prime}$ \\
\hline \multirow[t]{2}{*}{5} & $25^{\circ} 24^{\prime} 28.02^{\prime \prime}$ & $1 \mathrm{e}$ & $36^{\circ} 23^{\prime} 43.66^{\prime \prime}$ \\
\hline & $36^{\circ} 22^{\prime} 58.86^{\prime \prime}$ & & $25^{\circ} 25^{\prime} 25.90^{\prime \prime}$ \\
\hline \multirow[t]{2}{*}{6} & $25^{\circ} 24^{\prime} 3.77^{\prime \prime}$ & 1f & $36^{\circ} 23^{\prime} 32.57^{\prime \prime}$ \\
\hline & $36^{\circ} 23^{\prime} 21.52^{\prime \prime}$ & & $25^{\circ} 25^{\prime} 38.83^{\prime \prime}$ \\
\hline \multirow[t]{2}{*}{7} & $25^{\circ} 24^{\prime} 33.43^{\prime \prime}$ & $1 \mathrm{~g}$ & $36^{\circ} 23^{\prime} 28.14^{\prime \prime}$ \\
\hline & $36^{\circ} 23^{\prime} 21.59^{\prime \prime}$ & & $25^{\circ} 25^{\prime} 49.42^{\prime \prime}$ \\
\hline \multirow[t]{2}{*}{8} & $25^{\circ} 25^{\prime} 9.49^{\prime \prime}$ & $2 \mathrm{a}$ & $36^{\circ} 24^{\prime} 4.30^{\prime \prime}$ \\
\hline & $36^{\circ} 22^{\prime} 57.12^{\prime \prime}$ & & $25^{\circ} 25^{\prime} 21.33^{\prime \prime}$ \\
\hline \multirow[t]{2}{*}{9 (SN6a) } & $25^{\circ} 25^{\prime} 6.00^{\prime \prime}$ & $2 b$ & $36^{\circ} 23^{\prime} 56.57^{\prime \prime}$ \\
\hline & $36^{\circ} 23^{\prime} 17.88^{\prime \prime}$ & & $25^{\circ} 25^{\prime} 17.67^{\prime \prime}$ \\
\hline \multirow[t]{2}{*}{10} & $25^{\circ} 24^{\prime} 47.17^{\prime \prime}$ & $2 \mathrm{c}$ & $36^{\circ} 23^{\prime} 47.68^{\prime \prime}$ \\
\hline & $36^{\circ} 23^{\prime} 37.47^{\prime \prime}$ & & $25^{\circ} 25^{\prime} 17.07^{\prime \prime}$ \\
\hline \multirow[t]{2}{*}{11} & $25^{\circ} 25^{\prime} 37.48^{\prime \prime}$ & $2 d$ & $36^{\circ} 23^{\prime} 37.72^{\prime \prime}$ \\
\hline & $36^{\circ} 23^{\prime} 28.05^{\prime \prime}$ & & $25^{\circ} 25^{\prime} 23.32^{\prime \prime}$ \\
\hline \multirow[t]{2}{*}{12} & $25^{\circ} 24^{\prime} 54.90^{\prime \prime}$ & $2 \mathrm{e}$ & $36^{\circ} 23^{\prime} 31.82^{\prime \prime}$ \\
\hline & $36^{\circ} 23^{\prime} 50.40^{\prime \prime}$ & & $25^{\circ} 25^{\prime} 31.75^{\prime \prime}$ \\
\hline \multirow[t]{2}{*}{13 (SN6) } & $25^{\circ} 25^{\prime} 43.98^{\prime \prime}$ & $2 \mathrm{f}$ & $36^{\circ} 23^{\prime} 27.61^{\prime \prime}$ \\
\hline & $36^{\circ} 23^{\prime} 37.44^{\prime \prime}$ & & $25^{\circ} 25^{\prime} 40.78^{\prime \prime}$ \\
\hline \multirow[t]{2}{*}{14} & $25^{\circ} 25^{\prime} 21.79^{\prime \prime}$ & $3 a$ & $36^{\circ} 24^{\prime} 12.42^{\prime \prime}$ \\
\hline & $36^{\circ} 23^{\prime} 58.61^{\prime \prime}$ & & $25^{\circ} 25^{\prime} 17.41^{\prime \prime}$ \\
\hline \multirow[t]{2}{*}{15} & $25^{\circ} 24^{\prime} 54.94^{\prime \prime}$ & $3 b$ & $36^{\circ} 24^{\prime} 2.54^{\prime \prime}$ \\
\hline & $36^{\circ} 24^{\prime} 11.12^{\prime \prime}$ & & $25^{\circ} 25^{\prime} 11.65^{\prime \prime}$ \\
\hline \multirow[t]{2}{*}{16 (SN6b) } & $25^{\circ} 25^{\prime} 17.94^{\prime \prime}$ & $3 c$ & $36^{\circ} 23^{\prime} 52.08^{\prime \prime}$ \\
\hline & $36^{\circ} 24^{\prime} 13.68^{\prime \prime}$ & & $25^{\circ} 25^{\prime} 8.73^{\prime \prime}$ \\
\hline \multirow[t]{2}{*}{17} & $25^{\circ} 25^{\prime} 21.96^{\prime \prime}$ & $3 \mathrm{~d}$ & $36^{\circ} 23^{\prime} 39.78^{\prime \prime}$ \\
\hline & $36^{\circ} 24^{\prime} 41.28^{\prime \prime}$ & & $25^{\circ} 25^{\prime} 13.15^{\prime \prime}$ \\
\hline \multirow[t]{2}{*}{18} & $25^{\circ} 24^{\prime} 49.86^{\prime \prime}$ & $3 \mathrm{e}$ & $36^{\circ} 23^{\prime} 30.61^{\prime \prime}$ \\
\hline & $36^{\circ} 24^{\prime} 45.60^{\prime \prime}$ & & $25^{\circ} 25^{\prime} 21.94^{\prime \prime}$ \\
\hline 19 (SN7) & $25^{\circ} 24^{\prime} 30.90^{\prime \prime}$ & $3 f$ & $36^{\circ} 23^{\prime} 24.45^{\prime \prime}$ \\
\hline & $36^{\circ} 25^{\prime} 35.52^{\prime \prime}$ & & $25^{\circ} 25^{\prime} 32.97^{\prime \prime}$ \\
\hline Kam-1 & $25^{\circ} 23^{\prime} 12.54^{\prime \prime}$ & $3 \mathrm{~g}$ & $36^{\circ} 23^{\prime} 21.82^{\prime \prime}$ \\
\hline & $36^{\circ} 23^{\prime} 29.88^{\prime \prime}$ & & $25^{\circ} 25^{\prime} 46.43^{\prime \prime}$ \\
\hline Kam-2 & $25^{\circ} 23^{\prime} 14.52^{\prime \prime}$ & $4 \mathrm{a}$ & $36^{\circ} 24^{\prime} 9.96^{\prime \prime}$ \\
\hline & $36^{\circ} 23^{\prime} 44.70^{\prime \prime}$ & & $25^{\circ} 25^{\prime} 5.20^{\prime \prime}$ \\
\hline Kam-3 & $25^{\circ} 23^{\prime} 25.08^{\prime \prime}$ & $4 \mathrm{~b}$ & $36^{\circ} 23^{\prime} 58.17^{\prime \prime}$ \\
\hline & $36^{\circ} 23^{\prime} 40.98^{\prime \prime}$ & & $25^{\circ} 24^{\prime} 59.33^{\prime \prime}$ \\
\hline Kam-4 & $25^{\circ} 22^{\prime} 49.08^{\prime \prime}$ & $4 \mathrm{c}$ & $36^{\circ} 23^{\prime} 42.79^{\prime \prime}$ \\
\hline & $36^{\circ} 24^{\prime} 8.88^{\prime \prime}$ & & $25^{\circ} 24^{\prime} 57.73^{\prime \prime}$ \\
\hline Kam-5 & $25^{\circ} 22^{\prime} 57.84^{\prime \prime}$ & $4 d$ & $36^{\circ} 23^{\prime} 29.66^{\prime \prime}$ \\
\hline & $36^{\circ} 24^{\prime} 18.54^{\prime \prime}$ & & $25^{\circ} 25^{\prime} 6.01^{\prime \prime}$ \\
\hline Kam-6 & $25^{\circ} 23^{\prime} 8.52^{\prime \prime}$ & $4 \mathrm{e}$ & $36^{\circ} 23^{\prime} 20.74^{\prime \prime}$ \\
\hline & $36^{\circ} 24^{\prime} 41.04^{\prime \prime}$ & & $25^{\circ} 25^{\prime} 22.79^{\prime \prime}$ \\
\hline At-1 & $25^{\circ} 25^{\prime} 50.34^{\prime \prime}$ & & \\
\hline & $36^{\circ} 23^{\prime} 18.72^{\prime \prime}$ & & \\
\hline
\end{tabular}

Table 3 continued

\begin{tabular}{lll}
\hline Sampling site & Coordinates & Sampling site \\
\hline At-2 & $25^{\circ} 25^{\prime} 40.20^{\prime \prime}$ \\
& $36^{\circ} 23^{\prime} 14.76^{\prime \prime}$ \\
Fr-1 & $25^{\circ} 25^{\prime} 46.86^{\prime \prime}$ \\
& $36^{\circ} 23^{\prime} 40.32^{\prime \prime}$ \\
Fr-2 & $25^{\circ} 25^{\prime} 48.54^{\prime \prime}$ \\
& $36^{\circ} 23^{\prime} 44.70^{\prime \prime}$
\end{tabular}

Third sampling series

$\begin{array}{llll}\text { A1 } & 36^{\circ} 23^{\prime} 572 & \text { A2 }(2,20 \mathrm{~m}) & 36^{\circ} 23^{\prime} 63925^{\circ} 25^{\prime} 943 \\ & 25^{\circ} 25^{\prime} 914 & & \\ \text { A2 } & 36^{\circ} 23^{\prime} 639 & \text { A3 }(2,20 \mathrm{~m}) & 36^{\circ} 23^{\prime} 710 \\ & 25^{\circ} 25^{\prime} 943 & & 25^{\circ} 25^{\prime} 960 \\ \text { A3 } & 36^{\circ} 23^{\prime} 710 & \text { A4 }(2,20 \mathrm{~m}) & 36^{\circ} 23^{\prime} 779 \\ & 25^{\circ} 25^{\prime} 960 & & 25^{\circ} 25^{\prime} 952 \\ \text { A4 } & 36^{\circ} 23^{\prime} 779 & \text { B6 } & 36^{\circ} 23^{\prime} 921 \\ & 25^{\circ} 25^{\prime} 952 & & 25^{\circ} 25^{\prime} 738 \\ \text { A5 } & 36^{\circ} 23^{\prime} 839 & \text { B5 } & 36^{\circ} 23^{\prime} 870 \\ & 25^{\circ} 25^{\prime} 902 & & 25^{\circ} 25^{\prime} 785 \\ \text { A6 } & 36^{\circ} 23^{\prime} 903 & \text { S1 }(2,50 \mathrm{~m}) & 36^{\circ} 23^{\prime} 767^{\prime \prime} \\ & 25^{\circ} 25^{\prime} 847 & & 25^{\circ} 25^{\prime} 824^{\prime \prime} \\ \text { B6 } & 36^{\circ} 23^{\prime} 921 & \text { S2 } & 36^{\circ} 23^{\prime} 827^{\prime \prime} \\ & 25^{\circ} 25^{\prime} 738 & & 25^{\circ} 25^{\prime} 874^{\prime \prime} \\ \text { B5 } & 36^{\circ} 23^{\prime} 870 & \text { S3 } & 36^{\circ} 23^{\prime} 534^{\prime \prime} \\ & 25^{\circ} 25^{\prime} 785 & & 25^{\circ} 25^{\prime} 961^{\prime \prime} \\ \text { B4 } & 36^{\circ} 23^{\prime} 824 & \text { S4 } & 36^{\circ} 24^{\prime} 062^{\prime \prime} \\ & 25^{\circ} 25^{\prime} 843 & & 25^{\circ} 25^{\prime} 665^{\prime \prime} \\ \text { B3 } & 36^{\circ} 23^{\prime} 766 & \text { S5 } & 36^{\circ} 23^{\prime} 756^{\prime \prime} \\ & 25^{\circ} 25^{\prime} 822 & & 25^{\circ} 25^{\prime} 698^{\prime \prime} \\ \text { B2 } & 36^{\circ} 23^{\prime} 713 & 10 & 36^{\circ} 23^{\prime} 467^{\prime \prime} \\ & 25^{\circ} 25^{\prime} 882 & & 25^{\circ} 24^{\prime} 915^{\prime \prime} \\ & 36^{\prime} 23^{\prime} 638 & & \end{array}$


Table 4 Comparison of heavy metal concentration values from all sampling series with the safety limits for seawater set by US EPA (US EPA 2009)

\begin{tabular}{lclllll}
\hline Element & $\begin{array}{l}\text { Criterion of } \\
\text { maximum } \\
\text { concentration } \\
(\mathrm{CMC}, \mu \mathrm{g} / \mathrm{L})\end{array}$ & $\begin{array}{l}\text { Criterion of } \\
\text { constant } \\
\text { concentration } \\
(\mathrm{CCC}, \mu \mathrm{g} / \mathrm{L})\end{array}$ & $\begin{array}{l}\text { Limits } \\
\text { exceeded } \\
\text { 1st sampling } \\
\text { series }(\%)\end{array}$ & $\begin{array}{l}\text { Limits exceeded } \\
\text { 2nd sampling } \\
\text { series }(\%)\end{array}$ & $\begin{array}{l}\text { Limits exceeded } \\
\text { 3rd sampling } \\
\text { series }(\%)\end{array}$ & $\begin{array}{l}\text { Limits exceeded } \\
\text { 4th sampling } \\
\text { series }(\%)\end{array}$ \\
\hline Cadmium $(\mathrm{Cd})$ & 40.0 & 8.8 & $0 / 29(0)$ & $0 / 25(0)$ & $\mathbf{5 / 1 8 ~ C M C ~ ( 2 8 )}$ & $0 / 13(0)$ \\
Copper $(\mathrm{Cu})$ & 4.8 & 3.1 & $\mathbf{1 / 2 9} \mathrm{CMC}(\mathbf{3})$ & $0 / 25(0)$ & $0 / 18(0)$ & $0 / 13(0)$ \\
Lead $(\mathrm{Pb})$ & 210.0 & 8.1 & $0 / 29(0)$ & $0 / 25(0)$ & $\mathbf{5 / 1 8} \mathrm{CMC}(\mathbf{2 8}) \& \mathbf{3 / 1 8} \mathrm{CCC}(\mathbf{1 7})$ & $0 / 13(0)$ \\
Nickel $(\mathrm{Ni})$ & 74.0 & 8.2 & $0 / 29(0)$ & $0 / 25(0)$ & $0 / 18(0)$ & $0 / 13(0)$ \\
Chromium $(\mathrm{Cr}(\mathrm{VI}))$ & $1,100.0$ & 50.0 & $0 / 29(0)$ & $0 / 25(0)$ & $0 / 18(0)$ & $0 / 13(0)$ \\
Zinc $(\mathrm{Zn})$ & 90.0 & 81.0 & $0 / 29(0)$ & $0 / 25(0)$ & $0 / 18(0)$ & $0 / 13(0)$ \\
Mercury $(\mathrm{Hg})$ & 1.8 & 0.94 & $0 / 29(0)$ & $0 / 25(0)$ & $0 / 18(0)$ & $0 / 13(0)$ \\
\hline
\end{tabular}

Limits exceeded are marked with bold

total metal content of all heavy metals (except $\mathrm{Hg}$ ) in the sediment samples were determined after digestion with aqua regia according to standard EN 13657 and EN ISO 11885. For Hg, the EN 1483-E12-4 standard was used.

The significance of the combined examination of seawater and sediment samples

for the environmental contamination assessment of an area

The concentration of different heavy metals in surficial sediment samples is an important indicator for the overall assessment of the contamination of a particular area, since sediments are the final recipient of water intakes (Fytianos 1996). The presence of heavy metals in benthic sediments constitutes a potential danger for aquatic ecosystems. Sediments have high capability of accumulating and embodying heavy metals and organic contaminants even if their concentrations in the water column are relatively small. Their absorption/adsorption mechanisms depend on the nature of the sediments' particles, the properties of the absorbed contaminant and the existing physicochemical circumstances. Although most of the absorbed heavy metals in sediments are not biodegradable, it is possible, under certain mechanisms, to be released again in the water column. These mechanisms include sediment resuspension, adsorption, redox reactions and consumption from benthic flora. Consequently, sediment contamination with heavy metals can directly influence the seawater quality causing, thereby, adverse effects to the most sensitive levels of the food chain (Christophoridis et al. 2009). Due to the origin of heavy metals in sea sediments (anthropogenic or natural), there can be found in many forms, either strongly bound in the sediments' infrastructure or weakly absorbed in the solid-liquid interface. Many factors can influence the concentrations of heavy metals in sediments such as the mineralogy of the sediment, the $\mathrm{pH}$ and redox of seawater, precipitation and adsorption mechanisms and redox condition of the metals (Papaefthymiou et al. 2010). The largest percentage of the anthropogenic derived heavy metals in a sediment can be found in its most fine particles $(<63 \mu \mathrm{m})$ whereas in the sandy fraction, concentrations of heavy metals tend to diminish due to the existence of quartz grains usually found in this fraction (Islam and Tanaka 2004). The examination of sediments is, therefore, significant as well as necessary in order to have an overall environmental assessment of the contamination of an area.

\section{Results and discussion}

General observations from the four series of seawater sampling and comparison to EPA limits

Judging from the results of the first series of samples ( $n=29$, Fig. 1a), there is no particular correlation between metal concentrations and distance from the wreck point. According to the concentration limits of heavy metals in seawater set by the US EPA, shown in Table 1a, there was only one limit exceeded in the first series of samples (a $3 \%$ percentage of the total number of seawater samples examined), concerning copper in station 8 (4.80 ppb). This measurement could be random, but one should keep in mind that the corrosion of copper is a very slow procedure; thus, more measurements like this are expected in the future. Zinc was also measured in noteworthy concentrations (stations 12, 15 and 16) but within the permissible limits of Table 1a.

In the second sampling series $(n=25$, Fig. $1 b)$, no measured concentration value was above the EPA limits, and most elements exhibited values below detection limits. Only ferrous $(\mathrm{Fe})$ and manganese $(\mathrm{Mn})$ were measured in noteworthy but expected concentrations, taking into consideration the geochemical background of the area. 
Table 5 Mean values of metal concentrations from all the three series of sediment sampling

\begin{tabular}{|c|c|c|c|}
\hline \multirow[t]{2}{*}{ Element } & \multicolumn{3}{|l|}{ Mean value } \\
\hline & $\begin{array}{l}\text { First sampling series } \\
(n=10)\end{array}$ & $\begin{array}{l}\text { Third sampling series } \\
(n=10)\end{array}$ & $\begin{array}{l}\text { Fourth sampling series } \\
(n=11)\end{array}$ \\
\hline Lead $(\mathrm{Pb})$ & 63.4 & 24.9 & 27.4 \\
\hline Cadmium (Cd) & - & 10.7 & 2.1 \\
\hline Iron $(\mathrm{Fe})$ & 23,300 & 19,300 & 18,180 \\
\hline Copper $(\mathrm{Cu})$ & 48.8 & 18 & 14.3 \\
\hline Chromium (Cr) & - & 4.9 & 4.5 \\
\hline Manganese (Mn) & 370 & 275.7 & 265.5 \\
\hline Nickel (Ni) & 22.3 & 6.25 & 6.3 \\
\hline Mercury (Hg) & - & - & - \\
\hline Zinc (Zn) & 53 & 52.1 & 46.7 \\
\hline
\end{tabular}

$n=31$, values are presented in $\mathrm{mg} / \mathrm{kg}$ of dry matter. Average of three replicates

"-" Concentration values were below detection limit; thus, no mean value can be extracted

The third series of sampling $(n=18$, Fig. 2a) revealed the presence of $\mathrm{Cd}$ and $\mathrm{Pb}$ in elevated concentration values (1.3-6.5 and 1.2-6.5 ppm respectively), high above the CMC in five samples (a $28 \%$ percentage of the number of samples examined in the third series of sampling). Moreover, $\mathrm{Pb}$ was found in three more samples $(17 \%$ of the total samples) in concentrations exceeding the CCC limit. Since the samples have not been contaminated or mixed with other substances, serious concern is raised. It is most possible, if not random, that these significantly high concentrations may be the result of floating, non-obvious polyaromatic hydrocarbons (PAHs) escaped from the anticontaminant petroleum residue barrier (Gidarakos et al. 2011). Such concentration values of lead have also been observed in ship dismantling areas (Srinivasa Reddy et al. 2005). Furthermore, zinc was measured in relatively high concentrations in four stations (C3, $1, \Phi 2$ and $\Phi 3)$. These concentration values could possibly be related to its release from sacrificed anodes, propeller alloys or antifouling compounds such as $\mathrm{ZnPT}_{2}$, existing in "Sea Diamond."

Finally, in the fourth series of sampling $(n=13$, Fig. 2b), no concentration was measured above the EPA limits and only zinc ( $\mathrm{Zn}$ ) exhibited considerable values, which could possibly be related to "Sea Diamond" shipwreck for the same, as the above-mentioned, reasons.

All the aforementioned observations, numbers and percentages of samples exceeding EPA limits from all four series of seawater sampling are presented in Table 4 (provided also as electronic supplementary material). No statistical mean values can be given for the majority of metals in all series of seawater sampling due to a large number of measurements below detection limit, hence the lack of a unitary Table with mean values.
General observations from the three series of sediment sampling

The first series of sediment sampling ( $n=10$, Fig. 3) indicated noteworthy concentrations of $\mathrm{Mn}$ (370 ppm, mean value) and $\mathrm{Cu}$ (48.8 ppm, mean value), whereas $\mathrm{Zn}$, $\mathrm{Cr}$ and $\mathrm{Ni}$ concentration values were relatively low (Table 5). The manganese concentrations could be mainly attributed to the hydrothermal wells of the area rather than the shipwreck. Copper on the other hand, as it has been reported in other studies (Johnston et al. 2003, MacLeod et al. 2004) is one of the metals that will likely contaminate the sediments of the area in the long run, mostly because of its slow rate of corrosion and due to its wide presence in the hull. HFO (heavy fuel oil) is also capable of contaminating the sediments with copper by releasing it before the former one is collected by the use of anticontaminant petroleum residue barriers (Prego and Cobelo-Garcia 2004; SantosEcheandia et al. 2005).

During the second sampling series, no sediment samples were collected, hence the lack of a second sampling series column in Table 5.

The third sampling series $(n=10$, Fig. 3$)$ showed the same tendency as far as $\mathrm{Zn}, \mathrm{Cr}$ and $\mathrm{Ni}$ are concerned with the additional observation of high measurements of $\mathrm{Cd}$ in almost $25 \%$ of the samples (10.7 ppm, mean value, Table 5). Such concentrations of cadmium have never been observed in the caldera of Santorini before and are comparable only to concentrations measured in Piraeus, Alexandroupolis and Thermaikos harbor (Boboti et al. 1985; Poulos et al. 2007; Violintzis et al. 2009). All these three aforementioned harbors have been subjected to anthropogenic derived contamination sources. Since the estimated quantities of 
Fig. 4 Distribution of heavy metal concentrations of all the sediment samples in accordance with the a ERL/ERM and b TEL/PEL values
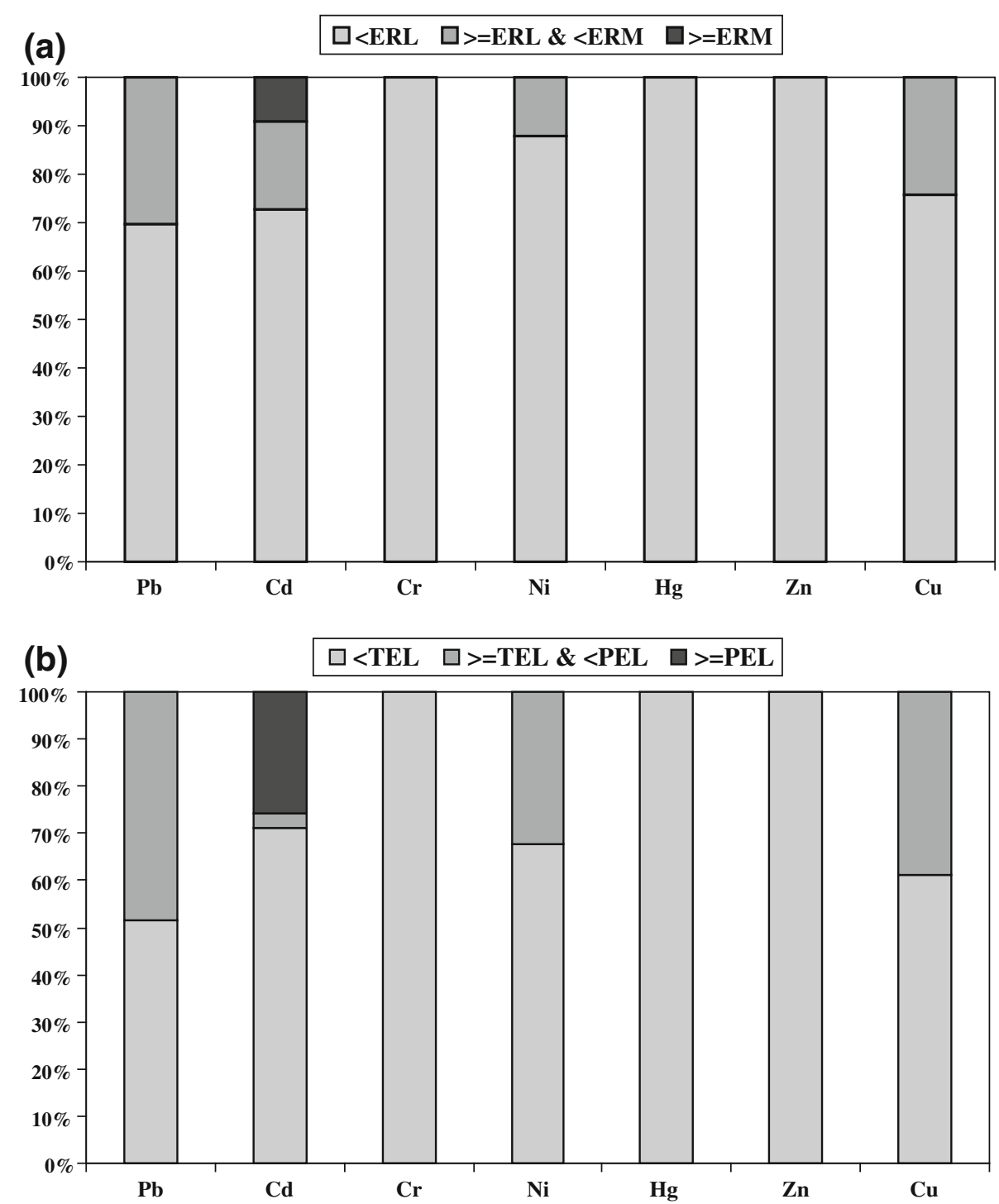

cadmium in the MS "Sea Diamond" are relatively low (see Table 5), it is our belief that these high concentration values most likely come from possible escape of petroleum residues (HFO) from the anticontaminant barrier (Gidarakos et al. 2011). Cadmium may also be present in other components/ parts of the ship that could not be feasible to estimate, since such concentrations have been reported in sediments nearby warship wreck (Johnston et al. 2003).

The fourth and last sampling series followed the exact tendency of the third in all metal concentrations (Table 5).

All series of sediment sampling revealed high levels of iron concentrations (1.6-2.7 w/w \%). These values, however, were expected due to the hydrothermal activity of the area and the geological background concentrations existing in bibliography (Varnavas and Cronan 2005). Taking into consideration the fact that iron ions do not completely transform into slug, it is possible that part of the iron existing in the hull of "Sea Diamond" will be corroded and thus contaminate even more the sediments in the long run (Michel and Helton 2003).

Similar conclusions to iron can be reported for the concentrations of manganese.

Application of SQGs for the contamination assessment of sediments from the surrounding wreck area

There are many methods for calculating the degree of metal contamination in the sediments of a particular area (Ridgway and Shimmield 2002). The most common ones are the enrichment factor (EF), the contamination factor (CF) and the modified degree of contamination $\left(\mathrm{mC}_{\mathrm{d}}\right)$ (Hakanson 1980). However, all of these pollution indicators use geological background/reference concentration values for their calculation. 
Santorini is an island presenting high levels of hydrothermal activity especially in the area where the wreck lies. This activity has resulted in a release of metals, such as iron and manganese, which precipitate selectively in various distances from the hydrothermal wells, thus creating metal zones of various concentrations both in sediments and in the water column (Varnavas and Cronan 2005).

As a consequence, therefore, there is a large bibliographic data for metal concentrations regarding the particular area as well as a wide range of reference concentrations due to the existence of these hydrothermal wells. The latter ones, coupled with the volcanic activity in Santorini, were the reasons for not following the pollution indicators" "path" that would possibly lead to precarious results. Instead, the authors chose to use the sediment quality guidelines (SQGs).

The use of SQGs is a common practice for evaluating the sediment contamination of an area (Leotsinidis and Sazakli 2008; Violintzis et al. 2009; Christophoridis et al. 2009; Kapsimalis et al. 2010). Two sets of guidelines were used: the ERL/ERM and TEL/PEL. The low range values (effects range low or threshold effect level) represent concentrations below which adverse effects upon living organisms in sediments are not likely to occur. Upper range values (effects range median or probable effects level) represent concentrations which are strongly affiliated with the appearance of adverse effects to aquatic organisms (Long et al. 1995; Burton 2002).

The ERL/ERM indicators use the 10 and $50 \%$ of metal concentrations that create adverse effects to benthic organisms, respectively. On the other hand, TEL/PEL indicators use the geometric mean of the aforementioned percentiles of concentration values that create or not adverse biological effects (Violintzis et al. 2009). Table 1b presents the ERL/ERM and TEL/PEL values for heavy metals in sediments. Figure 4 shows the distribution of heavy metal concentrations of all the sediment samples in accordance with the ERL/ERM and TEL/PEL values.

The results of Fig. 4 indicate that almost $25.8 \%$ of the sediments appeared to have $\mathrm{Cd}$ concentration values higher than the PEL limit, thus associating these values with frequent toxic effects on benthic organisms. However, the fact that $9.1 \%$ of the sediment samples appeared to have $\mathrm{Cd}$ concentrations higher than the ERM limit is a rather concerning one. Furthermore, 48.4 and $38.7 \%$ of $\mathrm{Pb}$ and $\mathrm{Cu}$, respectively, could be associated with occasional adverse biological effects, suggesting a contamination source near the wreck area, with possible direct suspect the MS “Sea Diamond." (Gidarakos et al. 2011)

A more realistic numerical approach for the sediments' toxicity can be given by using the mean quotients ERMQ and PELQ according to the following equations:
$\mathrm{ERMQ}=\sum_{i=1}^{n} M_{i} / \mathrm{ERM}_{i} / n$ and PELQ $=\sum_{i=1}^{n} M_{i} / \mathrm{PEL}_{i} / n$

where $M_{i}$ is the concentration of element $i$ in each sediment sample, $\mathrm{ERM}_{i}$ and $\mathrm{PEL}_{i}$ the guideline values for the examined element $i$, given in Table $1 \mathrm{~b}$, and $\mathrm{n}$ the number of metals. These formulas can be applied in case of multiple contaminants existing in the sediment that may result in an additive behavior in causing adverse effects. More specifically the classification of sediments according to ERMQ and PELQ is as follows:

ERMQ values of $<0.1,0.11-0.5,0.51-1.5$ and $>1.5$ are related to $12,30,46$ and $74 \%$, respectively, that sediments present toxicity in their dwelling fauna. Similarly, PELQ values of $<0.1,0.11-1.5,1.51-2.3$ and $>2.3$ are related to $10,25,50$ and $76 \%$, of toxicity, respectively (Long and MacDonald 1998; McCready et al. 2006).

The ERMQ for all the sediment samples taken was calculated and found to be 0.128 , whereas the PELQ was 0.24 . According to the aforementioned classification, the surrounding wreck area appears to have "low-to-medium" possibility $(25-30 \%)$ chance of presenting adverse toxic effects due to an additive behavior of all the heavy metals combined ( $\mathrm{Pb}, \mathrm{Cd}, \mathrm{Cr}, \mathrm{Ni}, \mathrm{Hg}, \mathrm{Zn}, \mathrm{Cu})$. These final results of mean quotients are attributed primarily in cadmium, nickel and lead and secondarily in copper and zinc. As far as chromium and mercury are concerned, there is no indication for any contribution in the contamination of the sediments of the area (also provided as electronic supplementary material).

Due to the volcanic activity of the area and the presence of hydrothermal wells, one could say that throughout the years the benthic community of the Caldera of Santorini has been possibly adopted to such "circumstances" and perhaps the concern of contamination that has arisen by the application of SQGs is not that important. This statement can also be sustained by the fact that SQGs do not take into consideration the natural fluctuations of the geological background of the area. Nevertheless, the high concentration values of cadmium and lead indicate the existence of a contamination source nearby stations SD1, SD2, SD3, a fact which could possibly lead to suspect the "Sea Diamond" shipwreck.

\section{Conclusion}

In the present study, the assessment and evaluation of heavy metal release due to the "Sea Diamond" shipwreck was aimed, and the results were compared with literature data on sediment quality guidelines and EPA concentration limits for heavy metals in seawater. 
Samples from the water column taken in the first two series of sampling showed low concentration values for all metals. However, the last two series revealed the abundant presence of $\mathrm{Pb}$ and $\mathrm{Cd}$ in concern levels. It is our belief though, that these high concentration values could be, if not random, a result of floating, non-obvious polyaromatic hydrocarbons (sheens) that could have escaped the anticontaminant barrier. Copper was also one of the metals found in relatively high concentration values in particular samples. Although $\mathrm{Cu}$ was, in general, found in normal levels, it is one of the elements that may create future problems due to its low rate of corrosion.

Zinc should also be taken into future consideration and examination.

Concentration values of copper in sediment samples showed an elevated tendency in comparison with previous measurements in the area, indicating that the sea sediments nearby the wreck will be contaminated in the future, up to a point, due to the corrosion of the ship or of the antifouling paints. Lead was another element that was present in high concentration levels. which according to ERL/ERM and TEL/PEL limits indicates anthropogenic contamination. It is also noteworthy that in 9.1 and $25.8 \%$ of the samples, cadmium concentrations were higher than the ERM and PEL limits, respectively, thus associating these values with frequent toxic effects on benthic organisms.

Acknowledgments This work was financially supported by the South Aegean Region and is gratefully acknowledged for this. The authors would also like to thank, for their dedication and cooperation for more than 2 years, all the scientists in Technical University of Crete and the colleagues of Laboratory of Toxic and Hazardous Waste management in TUC who were involved in the project of reporting and evaluating the current and long-term impacts of "Sea Diamond" shipwreck in the Caldera of Santorini, Greece.

\section{References}

Ansari TM, Marr IL, Tariq N (2004) Heavy metals in marine pollution perspective-a mini review. J Appl Sci 4:1-20

Boboti A, Stoffers P, Muller G (1985) Heavy metal pollution in the harbour area of Piraeus, Greece. Heavy Met Environ 2:407-410

Bu-Olayan AH, Subrahmanyam MNV, Al Sarawi M, Thomas BV (1998) Effects of the Gulf War oil spill in relation to trace metals in water, particulate matter, and PAHs from the Kuwait Coast. Environ Int 24:789-797

Burton GA (2002) Sediment quality criteria in use around the world. Limnology 3:65-75

Christophoridis C, Dedepsidis D, Fytianos K (2009) Occurrence and distribution of selected heavy metals in the surface sediments of Thermaikos Gulf, N. Greece. Assessment using pollution indicators. J Hazard Mater 168:1082-1091

Clark RB (2002) Marine pollution, 5th edn. Oxford University Press, New York

Environmental Protection Engineering S.A. (2008) Cruise ship "Sea Diamond" Green Passport
Fytianos K (1996) The contamination of seas. University Studio Press Pubs, Thessaloniki

Gidarakos E, Dimitrakakis E, Nakos A, Nomikos G, Venieri D, Liliana SM, Chapman C, Varoschuk I, Xekoukoulotakis N, Kordonouri E (2011) Reporting the qualitative and quantitative characterization of hazardous and toxic substances released from the "Sea Diamond" shipwreck-Evaluation of current and long term impacts, Unpublished Environmental Study. Technical University of Crete, Chania

Hakanson L (1980) Ecological risk index for aquatic pollution control, a sedimentological approach. Water Res 14:975-1001

Islam MS, Tanaka M (2004) Impacts of pollution on coastal and marine ecosystems including coastal and marine fisheries and approach for management: a review and synthesis. Mar Pollut Bull 48:624-649

Johnston RK, Halkola H, George R, In C, Gauthier R, Wild W, Bell M, Martore M, (2003) Assessing the ecological risk of creating artificial reefs from ex-warships. In: Oceans 2003 marine technology and ocean science conference. San Diego, CA, pp 851-860

Jones RJ (2007) Chemical contamination of a coral reef by the grounding of a cruise ship in Bermuda. Mar Pollut Bull 54:905-911

Kapsimalis V, Panagiotopoulos I, Kanellopoulos T, Hatzianestis I, Antoniou P, Anagnostou C (2010) A multi-criteria approach for the dumping of dredged material in the Thermaikos Gulf, Northern Greece. J Environ Manage 91:2455-2465

Leotsinidis M, Sazakli E (2008) Evaluating contamination of dredges and disposal criteria in Greek coastal areas. Chemosphere 72:811-818

Lin CL, Hu JH (2007) SAMHO BROTHER benzene ship accident. Mar Pollut Bull 54:1285-1286

Long ER, MacDonald DD (1998) Recommended uses of empirically derived sediment quality guidelines for marine and estuarine ecosystems. Hum Ecol Risk Assess 4:1019-1039

Long ER, MacDonald DD, Smith SL, Calder FD (1995) Incidence of adverse biological effects within ranges of chemical concentrations in marine and estuarine sediments. Environ Manage 19:81-97

MacLeod ID, Morrison P, Richards V, West N (2004) Corrosion monitoring and the environmental impact of decommissioned naval vessels as artificial reefs. In: Metal 04: international conference on metals conservation. Canberra, Australia, 4-8 October, pp 53-74

McCready S, Birch GF, Long ER (2006) Metallic and organic contaminants in sediments of Sydney Harbour, Australia and vicinity - a chemical dataset for evaluating sediment quality guidelines. Environ Int 32:455-465

Michel J, Helton D (2003) Environmental considerations during wreck removal and scuttling. In: AVP conference proceedings, national salvage conference

Mirlean N, Baraj B, Niencheski LF, Baisch P, Robinson D (2001) The effect of accidental sulphuric acid leaking on metal distributions in estuarine sediments of Patos Lagoon. Mar Pollut Bull 42:1114-1117

Papaefthymiou H, Papatheodorou G, Christodoulou D, Geraga M, Moustakli A, Kapolos J (2010) Elemental Concentrations in sediments of the Patras Harbour, Greece, using INAA, ICP-MS and AAS. Microchem J 96:269-276

Phull B (2010) Marine corrosion, Shreir's Corrosion. pp 1107-1148

Poulos S, Alexandrakis G, Karditsa A, Drakopoulos P (2007) Heavy metal investigation as pollutant indicators in bottom sediments in the harbours Heraklion and Alexandroupolis (Aegean Sea, Greece). In: Proceedings of the 10th international conference on environmental science and technology. Kos Island, Greece, 5-7 September 2007, pp B634-B641 
Prego R, Cobelo-Garcia A (2004) Cadmium, copper and lead contamination of the seawater column on the Prestige shipwreck (NE Atlantic Ocean). Anal Chim Acta 524:23-26

Ridgway J, Shimmield G (2002) Estuaries as repositories of historical contamination and their impact on shelf seas. Estuar Coast Shelf Sci 55:903-928

Rogowska J, Namieśnik J (2009) The assessment of the marine environment risk due to the presence of substances of ship wrecks origin - analytical problems. Analityka 3:52-54

Santos-Echeandia J, Prego R, Cobelo-Garcia A (2005) Copper, nickel, and vanadium in the Western Galician Shelf in early spring after the Prestige catastrophe: is there seawater contamination? Anal Bioanal Chem 382:360-365

Schreiber EA, Burger J (2002) Biology of marine birds. CRC Press, Boca Raton, FL, p 722

Srinivasa Reddy M, Basha S, Joshi HV, Ramachandraiah G (2005) Seasonal distribution and contamination levels of total PHCs,
PAHs and heavy metals in coastal waters of the Alang-Sosiya ship scrapping yard, Gulf of Cambay, India. Chemosphere 61:1587-1593

US Environmental Protection Agency (2009) National recommended water quality criteria, office of water, office of science and technology

Varnavas SP, Cronan DS (2005) Submarine hydrothermal activity of Santorini and Milos in the Central Hellenic Volcanic Arc: a synthesis. Chem Geol 224:40-54

Violintzis C, Arditsoglou A, Voutsa D (2009) Elemental composition of suspended particulate matter and sediments in the coastal environment of Thermaikos Bay, Greece: delineating the impact of inland waters and wastewaters. J Hazard Mater 166:12501260

Wikipedia (2012) Ms "Sea diamond" (internet). Available from ( http://en.wikipedia.org/wiki/MS_Sea_Diamond) 